Spring 3-1-2001

\title{
Ethics as Transformative Love: The Moral World of Etty Hillesum
}

Francis T. Hannafey S.J.

Fairfield University, fhannafey@fairfield.edu

Follow this and additional works at: https://digitalcommons.fairfield.edu/religiousstudies-facultypubs

\section{Peer Reviewed}

\section{Repository Citation}

Hannafey, Francis T. S.J., "Ethics as Transformative Love: The Moral World of Etty Hillesum" (2001). Religious Studies Faculty Publications. 55.

https://digitalcommons.fairfield.edu/religiousstudies-facultypubs/55

\section{Published Citation}

Hannafey, Francis T. "Ethics as Transformative Love: The Moral World of Etty Hillesum." Horizons 28.1 (Spring 2001): 68-80.

This item has been accepted for inclusion in DigitalCommons@Fairfield by an authorized administrator of DigitalCommons@Fairfield. It is brought to you by DigitalCommons@Fairfield with permission from the rightsholder(s) and is protected by copyright and/or related rights. You are free to use this item in any way that is permitted by the copyright and related rights legislation that applies to your use. For other uses, you need to obtain permission from the rights-holder(s) directly, unless additional rights are indicated by a Creative Commons license in the record and/or on the work itself. For more information, please contact digitalcommons@fairfield.edu. 


\title{
ETHICS AS TRANSFORMATIVE LOVE: THE MORAL WORLD OF ETTY HILLESUM
}

\author{
Francis T. Hannafey, S.J. \\ Fairfield University
}

\begin{abstract}
Etty Hillesum, a Dutch Jew who died at Auschwitz at the age of twenty-nine, left behind a diary and letters written during the last two years of her life. In An Interrupted Life and Letters from Westerbork, Hillesum tells a deeply moving story of religious experience, evil and suffering, spiritual growth, and interior and exterior moral transformation. While current scholarship on Hillesum focuses almost entirely on her personal life and religious journey, this essay examines the moral vision that emerges in her writings. Hillesum's diaries and letters present an engaging vision of the moral life-one that points with clarity to the importance of love of God and love of neighbor. This essay proposes that a love ethic is at the center of Hillesum's worldview and examines major influences on her religious and moral thought.
\end{abstract}

\section{Introduction}

Etty Hillesum, a Dutch Jew who died at Auschwitz at the age of twenty-nine, left behind a diary and letters written during the last two years of her life. ${ }^{1}$ Since the early nineteen-eighties English translations, An Interrupted Life and Letters From Westerbork, have been welcomed with high praise. Many around the world have been deeply moved by the writings of this young Jewish woman. One reviewer boldly claimed that the diaries represent "the most spiritually significant document of our age."2

In her diaries and letters Hillesum documents her experiences of God, moral evil, and human suffering. Her writings reveal a captivating

${ }^{1}$ I am especially grateful to my colleagues Nancy A. Dallavalle, Elizabeth A. Dreyer, Andrew J. Garavel, S.J., and to anonymous Horizons reviewers, for their helpful suggestions to improve this essay. An early version of this paper was presented at the Annual Meeting of the Society of Christian Ethics in Arlington, Virginia, January 8, 2000. I wish to thank those present who offered recommendations for improvement.

'Elizabeth O'Connor, “The Thinking Heart: A Feminine Spirituality From the Holocaust," Sojourners 14/9 (October 1985): 41.

Francis T. Hannafey, S.J. (Ph.D., 1998, Loyola University Chicago) is assistant professor of Religious Studies at Fairfield University (Fairfield, CT 06430) where he teaches Christian social ethics in the Religious Studies Department. He also teaches business ethics in the University's Applied Ethics Program. His research interests include Roman Catholic social teaching and business ethics. 
story of religious development and growth toward spiritual maturity. Current scholarship on Hillesum focuses almost entirely on her personal life and on her religious journey. ${ }^{3}$ Some authors have examined her writings in light of Jewish and Christian spiritual and mystical traditions. ${ }^{4}$ But the diaries and letters also present a vision of the moral life-one that points with engaging clarity to the central importance of love of God and love of neighbor. Love of God and neighbor becomes central to Hillesum's developing moral worldview.

Etty Hillesum writes during a dark period of modern history. She never denies the reality of the evil and suffering around her and she has no illusions about its horror. Despite this unspeakable moral chaos and cruelty, her diaries and letters reveal a deep and intimate experience of God that inspires in her own life a deep moral transformation. In $A n$ Interrupted Life, Etty Hillesum gradually moves from a narrow, individualistic moral worldview to one that embraces an intensely otherdirected ethic. Hillesum's story reveals a deep moral transformation, one grounded in a love that embraces all of humanity. Religious faith expands Hillesum's moral worldview and leads her to embrace the demands of moral obligation and responsibility to God and to others. The intense and growing love at the center of Hillesum's own religious experience forms the ground and source of her loving embrace of, and outreach to, those around her, especially those who are suffering.

This essay examines the structure of moral development in Hillesum's diaries and letters. While existing Hillesum scholarship focuses primarily on the importance of her work to spirituality, this study explores the rich yet unexamined moral reflection in her writings. Hillesum's encounter with God gradually leads her to look deeply into herself and to her moral responses to those in the world around her. In this essay I propose that a love ethic is at the center of Hillesum's moral

${ }^{3}$ See, e.g., Maureen Aggeler, "Women's Metaphors For Freedom," Supplement to The Way 74 (Summer 1992): 20-30; Calvin Bedient, "Outward from the Camps Themselves" in Martyrs: Contemporary Writers on Modern Lives of Faith, ed. Susan Bergman (San Francisco: Harper, 1996), 169-81; Bernard Weinstein, "Etty Hillesum's An Interrupted Life: Searching for the Human" in The Netherlands and Nazi Genocide, ed. G. Jan Colijn and Marcia S. Littell (Lewiston, NY: Edwin Mellen Press, 1992). For useful studies of the importance of writing and the spiritual life in Hillesum's life and work, see Denise De Costa, Anne Frank and Etty Hillesum: Inscribing Spirituality and Sexuality, tr. Mischa F. C. Hoyinck and Robert E. Chesal (New Brunswick, NJ: Rutgers University Press, 1998); see also Rachel Felday Brenner, Writing As Resistance: Four Women Confroning the Holocaust (University Park: Pennsylvania State University Press, 1997).

${ }^{4}$ See, e.g., Gregory Baum, "The Witness of Etty Hillesum, The Ecumenist 23 (January-February 1985): 24-28; Tina Beattie, "Love Without Limit," The Tablet 253 (24 July 1999): 1014-15; Lawrence S. Cunningham, "Letters From The Kingdom of Night: The Legacy of Etty Hillesum," Commonweal 114 (22 May 1987): 316-18; Richard R. Gaillardetz, "Etty Hillesum: Suffering and Sexuality, Reflections on Passionate Living," Spirituality 6 (May/June 2000): 148-52. 
worldview. This study examines the diaries and letters and the ways in which love is considered in them, explores the nature of Hillesum's love ethic, and then considers possible influences on her moral thought. Finally, I propose that Hillesum's love ethic is similar to that of St. Augustine, whom she draws upon in her diaries.

\section{Love and the Diaries}

Love and relationships are central to the diaries from the earliest entries. In 1941, while living in Amsterdam, Hillesum, aged 27, began keeping a diary, a practice she continued until near the end of her life. Hillesum, who showed a great capacity for relationships, describes them in the context of measures against the Jewish people, her prayer life, and a wide variety of personal experiences. The growth, development, and eventual transformation of her inner life and her maturing relationship with God form the central narrative of the diaries which beautifully describe her relationships with friends, family, and others. ${ }^{5}$ A number of striking patterns emerge: Hillesum reflects frequently on what she calls the "inner" and "outer" in her life; her growing sense of moral obligation to love all of humanity; and the serious problem of hatred in her world.

\section{The Inner and Outer}

Hillesum's early diary entries begin what becomes a sustained reflection on the "inner" and "outer" dimensions of her life. She describes many movements in her intense "inner" life of prayer. Her interest in reading, her vocation to writing, and her academic work as a linguist each provides in different ways connections between the "inner" and "outer" parts of her life. Hillesum searches for greater balance and integrity in the relationship between her rich "inner" life of prayer and her "outer" life in the world. Early in the diaries she writes, "There is a really deep well inside me. And in it dwells God. Sometimes I am there, too."6 Hillesum experiences God's love deep

${ }^{5} \mathrm{~A}$ number of authors have studied the transformative development in Hillesum's writings. These studies have directed most of their attention to the personal, religious, and spiritual changes discernable in these documents. See, e.g., Judy Cannato, "Transformation in Etty Hillesum: From Chaos To Order," Spiritual Life 40 (Summer 1994): 88-96; Michael Downey, "A Balm for All Wounds: The Spiritual Legacy of Etty Hillesum," Spirituality Today 40 (Spring 1988): 18-35; Elizabeth Liebert, "The Thinking Heart: Developmental Dynamics in Etty Hillesum's Diaries," Pastoral Psychology 43/6 (1995): 393-409.

${ }^{6}$ Etty Hillesum, An Interrupted Life and Letters From Westerbork (New York: Henry Holt, 1996), 44. Throughout this essay, references to the diaries and letters will be drawn from this volume that brings these documents together under one cover in English translation. References to Hillesum's writings will be cited as from the diaries or letters. 
within herself. As prayer becomes more important in her life, she gradually begins to move outside herself to others. Hillesum looks inward and seeks to simplify her newly begun practices of meditation "[s]o that something of 'God' can enter you, and something of 'Love,' too ... the love you can apply to small, everyday things." ${ }^{7}$ Hillesum finds love in many simple experiences of life: meals shared with friends, walks in the streets of Amsterdam, glimpses of nature's beauty, or conversations with strangers. Eventually, Hillesum expresses the moral sentiment that her "inner" life must reach out toward the outer moral world, even when this "outer" world is full of radical evil. She writes, "I try to face up to Your world, God, not to escape from reality into beautiful dreams." moves her outward to others. But her early diary entries do not begin this way.

At first, Hillesum comes across as selfish and possessive, and she herself speaks of her "grasping" personality and her desire to "own." Early in the diaries, her sense of love appears limited and self-focused. But the diaries reveal a gradual transition in her relational life to a more expansive, other-directed experience of love. As the diaries begin, Hillesum questions her newly formed intimate relationship with Julius Spier, whom she calls S. In her first entry March 1, 1941, while reflecting on her romantic relationships, she writes, "love does indeed suit me to perfection, and yet it remains a mere trifle, set apart from what is truly essential, and deep inside me something is still locked away." Discussing her relationship with S., she writes, "I am not in love with him." 10 She notes how she often can "revel in erotic fantasies for days and nights on end" and she complains about "that confounded eroticism, with which he is bursting, as am I." ${ }^{11}$ Yet Hillesum begins to discover greater freedom in her relationships which soon expands her experience of love.

The diaries point frequently to Hillesum's unconventional involvement with religion. It does not appear that she was involved in a formal way with a particular religious tradition. But in the diaries she often draws on the Jewish and Christian scriptures, as well as St. Augustine, her beloved poet Rainer Maria Rilke, and on a few occasions she refers to the Qur'an. With regularity she directly quotes Jewish and Christian biblical teaching on the love command. In one place she writes, "I have gradually come to realize that on those days when you

\footnotetext{
${ }^{7}$ Diaries, 28.

${ }^{8}$ Ibid., 135.

${ }^{9}$ Ibid., 3.

${ }^{10}$ Ibid., 7.

${ }^{11}$ Ibid., 8, 26.
} 
are at odds with your neighbors you are really at odds with yourself. 'Thou shalt love thy neighbor as thyself.",12 And again: "God created Man in His own image. Love thy neighbor as thyself." ${ }^{13}$ Referring to her initial efforts at formal prayer, she prays, "Let me perform a thousand daily tasks with love, but let every one spring from a greater central core of devotion and love." ${ }^{14}$ As the diaries progress, it becomes clear that Hillesum's vision of the moral demands of love is religiously grounded and inspired.

\section{Love of All Humanity}

As Hillesum describes with more frequency her experience of the transcendent, she also devotes striking attention to her growing sense of the moral obligation to love others. At this point in the diaries her many references to the moral demands of love become more expansive and outer-directed. Recalling a conversation recently shared with S., she writes, "love of mankind is greater than love of one man. For when you love one person you are merely loving yourself." 15 Later, she declares, "I have a sort of primitive love and primitive sympathy for people, for all people." 16 Similarly, she writes, "I shall try to spread some of my warmth, of my genuine love for others, wherever I go. But we shouldn't boast of our love for others." ${ }^{17}$ As her thought matures, Hillesum begins to see that real love requires moral treatment of others. At many points in the diaries she struggles with her own admitted selfishness. She speaks of her struggle to love her parents and at the same time to allow them their freedom: "What shall it profit a man if he has no love? Fine theories to make you feel comfortable and noble, but in practice you shrink from even the smallest act of love. No, what is needed here is not a small act of love. It is something fundamental and important and difficult. To love your parents deep inside."18 Hillesum eventually discovers that an inner religious life cannot be separated from the outer moral life. Recalling a conversation with her friend Jan Bool about tightened restrictions on the Jewish people and of the motivations of human beings that often make them want to destroy others, she responds to her friend and declares, "[t]he rottenness of others is in us, too." ${ }^{19}$ For Hillesum, moral virtue in the outer world is only pos-

${ }^{12}$ Ibid., 64.

${ }^{13}$ Ibid., 66.

${ }^{14}$ Ibid., 70.

${ }^{15}$ Ibid., 33.

${ }^{16}$ Ibid., 53.

${ }^{17}$ Ibid., 63.

${ }^{18}$ Ibid., 66.

${ }^{19}$ Ibid., 84. 
sible because of an inner moral transformation-and this inner change more than anything else involves love.

As the diaries progress, Hillesum shows an expansive sense of the moral importance of loving others. She asks one evening, "Why shouldn't one feel an immense, tender ecstasy of love for the spring, or for all humanity?" ${ }^{20}$ Hillesum discovers moral strength in "the feeling of love, not just for one man, for one paltry man, but for everyone with whom one happens to share one's life."21 This sentiment is repeated when she decides she does not want to marry S. Hillesum describes her desire to express her love more widely. She writes, "Sustained hourly by the love I bear him and others . . . I would rather be alone and there for everyone." ${ }^{22}$ Hillesum is aware of an ongoing moral transformation inside herself when she observes that "[t]he love I now feel is different, wider." ${ }^{23}$ At one point, she herself describes this as "[a] gradual change from the physical to the spiritual."24 Hillesum finds new inner peace, balance, and calm in her life-and her stance in the outer moral world is dramatically transformed.

\section{The Problem of Hatred}

The central importance of love in Hillesum's moral vision is further clarified as she reflects on the war and the situation facing the Jewish people. Hillesum depicts hatred as a major cause of the war and expresses regret that hatred is very often the response of those who suffer from the war's injustice. Hillesum recognizes the enormous moral problems that arise when hatred of others is the response to moral evil and violence. She is critical of hatred in all its forms, even when it seems to be morally justified. She writes, "All disasters stem from us. Why is there a war? Perhaps because now and then I might be inclined to snap at my neighbor. Because I and my neighbor and everyone else do not have enough love. Yet we could fight war and all its excrescences by releasing, each day, the love that is shackled inside us, and giving it a chance to live. And I believe that I will never be able to hate any human being for his so-called wickedness." ${ }^{25}$ For Hillesum, responding with hatred to the violence and injustice around her only makes matters worse.

Hillesum is not naive about the horrendous moral evil unleashed in her world. Yet, amazingly, even in this environment, she continues

\footnotetext{
${ }^{20}$ Ibid., 89.

${ }^{21}$ Ibid., 110.

${ }^{22}$ Ibid., 195.

${ }^{23}$ Ibid., 71.

${ }^{24}$ Ibid., 92.

${ }^{25}$ Ibid., 95.
} 
to speak of the transforming moral power of love. At one point she acknowledges "the ocean of human suffering" and "hatred" so much a part of the war. ${ }^{26}$ Then, she immediately compares the response to this suffering to how one loves: "[o]ne should be less and less concerned with the love object and more and more with love itself, if it is to be real love." ${ }^{27}$ She writes, "genuine moral indignation must run deep and not be petty personal hatred." ${ }^{28}$ She further states that "we must look at all that indignation we feel and discover whether its roots are genuine and deep and truly moral." ${ }^{29}$ Hillesum is remarkable in her capacity for deeply nuanced moral discernment.

Hillesum believes that even greater moral chaos arises for those who respond to injustice and evil with hatred. She writes, "indiscriminate hatred is the worst thing there is" and later observes, "[d]o not relieve your feelings through hatred." ${ }^{30}$ In a prayer, she asks, "God, do not let me dissipate my strength, not the least little bit of strength, on useless hatred against these soldiers." ${ }^{31}$ Even as life for the Jewish people of Amsterdam worsens, she writes, "I hate nobody. I am not embittered. And once the love of mankind has germinated in you, it will grow without measure."32 Hate and disregard for others-even for those who directly participate in persecution of the innocent-have no place in Hillesum's moral worldview.

\section{An Ethic of Love}

Hillesum's experience of prayer leads her to discover a deep sense of moral responsibility to love God and her neighbor. As her life of prayer grows and matures, so does her attention to the moral demands of love. In a 1996 study, Joan Penzenstadler describes the importance of Hillesum's increasing attentiveness to the spiritual life and observes that "[t]hrough prayer, her love became more and more expansive."33

${ }^{26}$ Ibid., 129.

${ }^{27}$ Ibid., 129.

${ }^{28}$ Ibid., 130.

${ }^{29}$ Ibid., 130.

${ }^{30}$ Ibid., 11, 97.

${ }^{31}$ Ibid., 109.

${ }^{32}$ Ibid., 180-81. On various occasions, Hillesum describes conversations shared with friends about hate of those persecuting the Jewish people. In one diary entry, Hillesum recalls a conversation shared with her friend Klaas Smelik, during which she explains her view that hate leads only to moral chaos. She observes, "[w]e shan't get anywhere with hatred, Klaas" (Diaries, 210). Further, "we shouldn't even be thinking of hating our so-called enemies" (Diaries, 211). She told Klaas that "every atom of hate we add to this world makes it still more inhospitable" (Diaries, 212).

${ }^{33}$ Joan Penzenstadler, "Attentive to Transcendence: The Life of Etty Hillesum" in Wagering on Transcendence: The Search for Meaning in Literature, ed. Phyllis Carey (Kansas City, MO: Sheed and Ward, 1997), 43. 
Soon after volunteering to accompany the first group of Jews sent to the Westerbork transit camp, and following the death of her intimate friend S., she prays, "[w]ith the passing of people, I feel a growing need to speak to You alone. I love people so terribly, because in every human being I love something of You. And I seek You everywhere in them and often do find something of You." ${ }^{34}$ Hillesum's own experience of God's love leads her to the recognition of a moral obligation to love her neighbor.

The love ethic present in Hillesum's writings is extraordinary when considering the realities of her own difficult life in a violent world. After the death of S., she reflects on life at Westerbork during a time when her love is deeply tested. Still, her own experience of God's love and love for others is transformative for her. In this especially difficult period of her life, Hillesum maintains that the most human and moral of acts is to love. She writes, "Even if one's body aches, the spirit can continue to do its work, can it not? It can love. . . "35 While at Westerbork, Hillesum uses the word "love" a number of times to describe her stance before God, life, and others. She writes, "And there among the barracks, full of hunted and persecuted people, I found confirmation of my love of life." ${ }^{36}$ Struggling with her own health at Westerbork, Hillesum reflects on her own efforts to put this love into action. She reaches out to those around her, particularly to children, the elderly, and strangers. She shares time, food, and kind, supportive conversation with many she lives with in the camp. While struggling with difficult health problems, she states, "I want to be sent to every one of the camps that lie scattered all over Europe, I want to be at every front . . . I want to fraternize with all my so-called enemies." ${ }^{37}$ Further, she writes, "I am not afraid to look suffering straight in the eyes. And at the end of each day, there was always the feeling: I love people so much. Never any bitterness about what was done to them, but always love for those who knew how to bear so much although nothing had prepared them for such burdens." ${ }^{38}$ Hillesum's own suffering taught her how to love others who were also suffering.

As the diaries conclude, Hillesum refers directly to morality on a number of occasions. Recalling her early life of active pleasure seeking, she writes, "[i]f one wants to exert a moral influence on others, one

\footnotetext{
${ }^{34}$ Diaries, 198.

${ }^{35}$ Ibid., 204. Further, Hillesum writes, "I have learned to love Westerbork." See Diaries, 205.

${ }^{36}$ Ibid., 209. In this same entry, Hillesum also writes that in the camp she has still discovered "how lovely and worth living and just-yes, just-life really is." See Diaries, 209.

${ }^{37}$ Ibid., 223.

${ }^{38}$ Ibid., 227.
} 
must start with one's own morals." ${ }^{39}$ Hillesum's understanding of moral obligation draws on human interiority, particularly from the place deep within where the human meets God. She writes, "[u]ltimately, we have just one moral duty: to reclaim large areas of peace in ourselves, more and more peace, and to reflect it toward others. And the more peace there is in us, the more peace there will also be in our troubled world." ${ }^{40}$ Hillesum's own inner experience of God's gratuitous love transforms her vision of the moral life.

Hillesum does not deny or ignore the reality of the evil around her. Yet it is clear in the diaries that she continues to experience enduring goodness in life. Aware that she remains in the "real world," she asks, "[w]hy not turn the love that cannot be bestowed on another, or on the other sex, into a force that benefits the whole community and that might still be love? And if we attempt that transformation, are we not standing on the solid ground of the real world, of reality?"41 Hillesum sees the moral life as including the obligation to love "the whole community." Her experience of loving union with God leads her to discover a moral duty to love others.

\section{Love and the Letters}

In early June 1943, Hillesum left Amsterdam for the last time and traveled to Westerbork, a transit camp in eastern Holland where she spent the final months of her life. Edith Stein is also known to have passed through Westerbork before she was killed at Auschwitz in August 1942. At Westerbork, Hillesum wrote many letters, and in them we meet a twenty-nine year old woman with deep moral sensibilities and an inspiring love of humankind. In these letters Hillesum reflects seriously on moral questions. In December 1942, while on leave from the camp during a visit to Amsterdam, she was commissioned to write about her experiences there and in this account she expresses concern that at Westerbork "there is the great moral danger of becoming blunted and hardened." 42 Like the diaries, the letters also contain remarkable considerations of a variety of moral questions.

In her letters Hillesum continues to reflect on the moral importance of love and on the problem of hatred. Evaluating the responses of many to the injustice of the camp, she writes, "I know that those who

${ }^{39}$ Ibid., 216.

${ }^{40}$ Ibid., 218.

${ }^{41}$ Ibid., 208.

${ }^{42}$ Letters, 250. This letter was composed in Amsterdam (18 December 1942), and is one of two letters by Hillesum that were published illegally by the Dutch Resistance in 1943. In it, Hillesum responds to a request to describe in some detail life at Westerbork. 
hate have good reason to do so." ${ }^{43}$ Then she proceeds to name the hatred which flows from justified moral indignation to be "the cheapest and easiest way" and observes that "every atom of hatred added to the world makes it an even more inhospitable place." ${ }^{\text {4 }}$ On a few occasions, Hillesum draws on the writings of St. Paul to express her view that love is central in the moral life. She cites St. Paul's well-known statement on love, and writes: "And I also believe, childishly perhaps but stubbornly, that the earth will become more habitable again only through the love that the Jew Paul described to the citizens of Corinth in the thirteenth chapter of his first letter." 45

At Westerbork, Hillesum shows great personal concern for those struggling the most, especially children and the elderly. The letters reveal her continuing care for her parents, family, and friends. In a number of places, she states that she is glad to return to the camp since there she can be with those who need her. Hillesum refuses to take the option to go to a camp for "elite" cultural Jews. The letters describe her concern for many strangers she meets, some of whom are suffering greatly. In a fragment of a letter addressed to her friend Father Han and others, she draws on Christ's teaching on the command to love God above all else, even prior to family, and writes, "we have little thought or love left for our neighbors. More and more I tend toward the idea that love for everyone who may cross your path, love for everyone made in God's image, must rise above love for blood relatives." ${ }^{46}$ Following a similar pattern in the diaries, Hillesum's love ethic appears to include a sense of impartiality.

Hillesum's life of prayer enabled her to experience love-both God's love and the love of others-in a situation of radical injustice and great suffering. The final letters are effusive in conveying Hillesum's experience of a profound peace and calm as the situation in the camp worsens. She quotes a letter from her friend Leguit: "[a]nd yet God is love." 47 She then observes, "I completely agree, and it is truer now than ever." 48 In a striking assertion about the response of love to moral chaos, she writes "[a]gainst every new outrage and every fresh horror, we shall put up one more piece of love and goodness, drawing strength

${ }^{43} \mathrm{Ibid} ., 256$. This reference appears at the conclusion of the letter composed in Amsterdam, 18 December 1942, cited above.

${ }^{44}$ Ibid.

${ }^{45}$ Ibid. See also 1 Cor 13.

${ }^{46}$ Ibid., 334. This is a fragment of a letter to Father Han and others, undated, after 18 August 1943.

${ }^{47}$ Ibid., 287. This letter written from Westerbork is addressed to Little Father Han, Kathe, Maria, Hans, and is dated 29 June 1943.

${ }^{48}$ Ibid. 
from within ourselves." 49 In this same letter, she writes that "one day we shall be building a whole new world."50 Similarly, to her close friend Maria Tuinzing she observes: "Many feel that their love of mankind languishes at Westerbork because it receives no nourishmentmeaning that people here don't give you much occasion to love them. ... [b]ut I keep discovering that there is no causal connection between people's behavior and the love you feel for them. Love for one's fellow man is like an elemental glow that sustains you. The fellow man himself has hardly anything to do with it. Oh Maria, it's a little bit bare of love here, and I myself feel so inexpressibly rich; I cannot explain it."51 Hillesum continues to reaffirm the view in her letters that love is the essential basis of morality.

\section{Ethics as Transformative Love}

In a study of Hillesum's spiritual vision, Judy Cannato has observed that her writings tell a story of personal transformation. Cannato suggests that one cannot encounter these documents "without being touched by the honesty and depth of love of this young Jewish woman." 52 Cannato writes further that Hillesum's "great capacity for love of all human beings came from within her. Her response to atrocities was to look within and root out the evil within herself." ${ }^{33}$ Considering personal conflicts in Hillesum's own life, Cannato concludes her essay by suggesting that for Hillesum "these issues were not moral." 54 However, as I have argued in this essay, Hillesum does reflect often on questions of morality in her own inner and outer worlds, including behavior in her own personal life. Hillesum's writings tell not only a story of personal and spiritual transformation, as Cannato well describes. The diaries and letters also tell a story of deep moral transformation.

It must be acknowledged that there are complexities, moral ambiguities, and contradictions in Hillesum's writings and in her own life. Hillesum's personal life-for example, her admitted selfishness, her many sexual partners, and her references in the diaries to a possible abortion-point to significant moral conflict in her own life. While these contradictions in her writings are real, it is also clear that her life is radically changed as the diaries and letters conclude. God's grace

\footnotetext{
${ }^{49} \mathrm{Ibid}$., 294. This letter written from Westerbork ( 3 July 1943) is addressed to Jopie, Klaas, and to "dear friends."

${ }^{50}$ Ibid.

${ }^{51}$ Ibid., 323. This letter from Westerbork (7 August 1943) is addressed to Maria.

${ }^{52} J u d y$ Cannato, "Transformation in Etty Hillesum: From Chaos to Order," 95.

${ }^{53}$ Ibid.

${ }^{54}$ Ibid.
} 
changes her; her new life of prayer brings about in her a deep moral transformation. Hillesum's experience of grace eventually moves her to greater fidelity and accountability in her own moral behavior and in her relationships with others.

Some years ago Stanley Hauerwas examined the difficulties posed by a love ethic and argued that a central task of the moral life is to face reality as it is. Hauerwas has suggested that "love is not the saving of others from suffering, but the willingness to continue to love them in their suffering." ${ }^{55}$ Hillesum does just this. Her love of those around her during the final months of her life-as told by friends who survived her and as revealed to us in her diaries and letters-points to the enduring human experience that love is fundamental to the moral life. Hillesum's experience of God's grace expands her own moral horizon to include the reaching out to others in love. Her own inner moral life is transformed in an outer environment of moral chaos, moral evil, and human suffering. Hillesum, who describes the human person as created as an imago Dei, comes to accept that the loving union she shares with God requires her to love her neighbor. Her experience of moral obligation moves her to take direct initiative in caring for her neighbor. Hillesum experiences a deep call to love God, her neighbor, and even her enemies.

\section{Hillesum and Religious Traditions}

Hillesum does not identify herself with any one religious tradition; her love ethic is neither strictly Jewish nor Christian. Yet the Jewish and Christian scriptures, St. Augustine, and the writings of Rainer Maria Rilke inspire her. The gospels appear to influence her moral thinking significantly. She often draws on the Gospel according to Matthew and cites its moral teachings. ${ }^{56}$ On a few occasions, Hillesum's references to this gospel draw directly on the love command in Matthew 22:37-40. ${ }^{57}$ Hillesum refers to Christianity and to Christ in a number of places in the diaries. ${ }^{58}$ She also considers the Christian celebration of Easter on at least four occasions. ${ }^{59}$ However, it is not possible to situate Hillesum's moral vision too closely within a single religious tradition. While Judaism and Christianity are considerable religious influences in the diaries and letters, Hillesum's own highly personal

\footnotetext{
${ }^{55}$ Stanley Hauerwas, "Love's Not All You Need" in Vision and Virtue: Essays in Christian Ethical Reflection (Notre Dame, IN: University of Notre Dame Press, 1981), 126.

${ }^{56}$ See, e.g., the Diaries, 108, 110, 213, 215. In these entries, Hillesum refers to her reading of this Gospel or quotes parts of the biblical text directly.

${ }^{57}$ See, e.g., Diaries, 66. See also Matthew 22:37-40.

${ }^{58}$ See Diaries, 67, 98, 201, 212.

${ }^{59}$ See Diaries, 112, 113, 114, 115.
} 
and-to some-mystical religious experience may have also inspired her moral thinking.

The writings of St. Augustine appear to have influenced deeply the formation of Hillesum's love ethic. Hillesum refers to Augustine at various places in the diaries, which are written in the form of a prayer dialogue-not unlike the Confessions. ${ }^{60}$ Like Augustine, Hillesum's diaries work through a tense dialectical relationship between "body" and "soul." She struggles with her sexuality and the erotic dimensions of her love relationships. She also shares with Augustine the view that the human person is created in the image of God. In one entry, she writes: "I am going to read Saint Augustine again. He is so austere and so fervent. And so full of simple devotion in his love letters to God. Truly those are the only love letters one ought to write: love letters to God." ${ }^{61}$ Like Augustine, Hillesum begins to recognize that all love is ultimately referred to God. She expresses the Augustinian view that the human person both reaches union with God and responds to the demands of such union by and through self-giving love. For Hillesum, religious experience ultimately leads her to accept that love of God is the very foundation of true moral love of neighbor.

\section{$X$. Conclusion}

Hillesum's moral vision is distinctive and inspiring. The love ethic that emerges in her writings reveals a distinctive religious source and grounding, although it is not an ethic based primarily on law or moral mandate. Hillesum's love ethic might be better described as an "affective-centered" approach rather than one that is "norm-centered."62 Such an approach sees love for God as the central context for love of neighbor. ${ }^{63}$ Her great concern for others at the end of her life displays a radically altruistic love. Hillesum's relationship with God expands her own moral horizon to include the deepest reaching out to others in love. As told by friends who survived her and as revealed to us in her writings, Hillesum's love of those around her at Westerbork points clearly to the enduring experience of humanity that love is central in the moral life-a truth that can and must speak to us in our time.

${ }^{60}$ See Diaries, 134, 139, 146, 228.

${ }^{61}$ Diaries, 228.

${ }^{62}$ Stephen J. Pope, in a helpful study of love in contemporary Christian ethics, uses these terms to describe various approaches to love ethics. See his "Love in Contemporary Christian Ethics," Journal of Religious Ethics 23/1 (Spring 1995): 167-97.

${ }^{63}$ Ibid., 167; 181-83. 